\title{
Reduced Graphene Oxide-Zinc Oxide Flower-Like Composite for Glass-Ionomer Materials Reinforcement
}

\author{
Ana Paula Benevides ${ }^{a}$ (), Adriano Rocha Campos ${ }^{b}$,Lanna Cristina Vieira ${ }^{b}$, Cesar dos Reis Perez ${ }^{b}$, \\ Deborah Vargas Cesar ${ }^{a *}$ (D)
}

\begin{abstract}
${ }^{a}$ Universidade do Estado do Rio de Janeiro, Instituto de Quimica (IQ), Departamento de Quimica Analítica (DQA), Laboratório de Materiais para Engenharia Química, Rio de Janeiro, RJ, Brasil ${ }^{b}$ Universidade do Estado do Rio de Janeiro (UERJ), Faculdade de Odontologia (FO), Vila Isabel, Rio de Janeiro, RJ, Brasil
\end{abstract}

Received: October 20, 2019; Revised: January 9, 2020; Accepted: January 29, 2020

\begin{abstract}
Composites based on graphene oxide (GO), reduced graphene oxide (RGO) and zinc oxide ( $\mathrm{ZnO})$ with different mass ratios $(8,100$ and 600$)$ were synthesized through the hydrothermal method at $100{ }^{\circ} \mathrm{C}$ and used as reinforcement materials to commercial glass-ionomers cements (GIC). X-ray diffraction (XRD) characterization confirmed the graphite oxidation and $\mathrm{ZnO}$ formation as a wurtzite phase. Infrared spectroscopy analyses showed bands of oxygen-containing groups on the GO surface, which reduced after thermal treatment and RGO formation. D and G bands were observed in all samples synthesized, which presented morphology similar to flowers with a crystallite size of $18 \mathrm{~nm}$. The effect on the mechanical properties of GIC after reinforcement with $0.1 \mathrm{wt} \%$ of RGO and $3 \mathrm{wt} \%$ of the composites was evaluated using a one-way analysis of variance (ANOVA). It was verified slight improvements in the hardness of GIC.
\end{abstract}

Keywords: Reduced graphene oxide, ZnO composites, glass-ionomer cement, mechanical properties, physicochemical characterization.

\section{Introduction}

Graphene has received substantial attention due to its unique properties such as high surface area, electron conductivity, chemical, and thermal stability ${ }^{1-3}$. The synthesis of graphene is mainly based on Hummers and Offeman method ${ }^{4}$, which produces graphene oxide $(\mathrm{GO})$ that is reduced using chemical or thermal methods to form graphene or reduced graphene oxide $(\mathrm{RGO})^{5-10}$. Graphene is formed by only one sheet, so the number of stacked sheets defines the material as graphene or $\mathrm{RGO}^{11}$. Graphene-based materials have textural and structural properties that enable the use in energy storage, photoreduction, supercapacitors, solar cells, drug delivery, adsorption, reinforcement of Al-based composites ${ }^{12-14}$ and filtration systems ${ }^{1,6,15-18}$. Also, graphene presents excellent mechanical properties (fracture toughness of $42 \mathrm{~N} / \mathrm{m}$ and Young's modulus of $1.0 \mathrm{TPa})^{19}$, biocompatibility, chemical stability, and favorable tribological properties by reducing wear and friction ${ }^{20}$.

Glass ionomer cements (GICs) represent a group of materials with extensive applications in dentistry and medicine: luting cement, restoration of deciduous and permanent teeth, minimally invasive restorative techniques, and bone substitute plates for craniofacial reconstruction ${ }^{21}$. However, conventional GICs present poor mechanical properties such as wear resistance, which limits its use to areas with lower stress. Several efforts have been made to improve

*e-mail:dvargas@uerj.br its properties, such as the inclusion of metallic particles ${ }^{22}$, composite resins ${ }^{23,24}$, microfibers ${ }^{25}$, among others. Also, additives like chlorhexidine and zinc are used to improve antimicrobial GICs properties ${ }^{26,27}$. The antimicrobial properties of zinc oxide $(\mathrm{ZnO})$ are extensively studied, which are improved by surface area, particle size, morphology, and surface charge ${ }^{28,29}$. Though, there are few studies about its effect on the mechanical properties of $\mathrm{GICs}^{30}$.

Graphene and its derivatives have been tested for mechanical reinforcement of certain materials in dentistry ${ }^{31}$, as in hydroxyapatite composites ${ }^{32}$, in calcium silicate cement $^{33}$, in polymethyl methacrylate ${ }^{34-36}$ and glass-ionomer cement $^{37,38}$. In these works, there were reported improvements in mechanical properties with the incorporation of graphene or its derivatives.

However, a drawback for the use of RGO in dental materials is its dark color. In this matter, Sun et al. ${ }^{38}$ have fluorinated graphene, and Zanni et al. ${ }^{28}$ have added zinc oxide to graphene nanoplatelets to obtain a lighter compound, but it was not incorporated into GICs materials.

Therefore, this work presents the evaluation of the properties of glass-ionomer materials after reduced graphene oxide/ZnO composite addition, used for reinforcement. The composite was obtained by hydrothermal method and was structural and morphologically characterized by X-ray diffraction (XRD), Fourier transform infrared absorption spectroscopy (FTIR), and scanning electron microscopy (FEG-SEM). 


\section{Experimental}

\subsection{Chemicals}

Graphite (Grafine 996100, kindly provided by Nacional de Grafite, Brazil), sulfuric acid ( $\mathrm{H}_{2} \mathrm{SO}_{4} 95 \mathrm{wt} \%$, VETEC), potassium permanganate $\left(\mathrm{KMnO}_{4}, 99 \mathrm{wt} \%\right.$, ISOFAR), sodium nitrate $\left(\mathrm{NaNO}_{3}, 98 \mathrm{wt} \%\right.$, ISOFAR) and hydrogen peroxide $\left(\mathrm{H}_{2} \mathrm{O}_{2}, 30 \mathrm{wt} \%\right.$, ISOFAR $)$, zinc nitrate hexahydrate $\left(\mathrm{Zn}\left(\mathrm{NO}_{3}\right)_{2} \cdot 6 \mathrm{H}_{2} \mathrm{O}, 98 \mathrm{wt} \%\right.$, VETEC) and urea $\left(\mathrm{CH}_{4} \mathrm{~N}_{2} \mathrm{O}, 99 \mathrm{wt} \%\right.$, VETEC). Commercial GICs (Vidrion R, SS White, Rio de Janeiro, Brazil).

\subsection{Synthesis of graphene oxide $(G O)$ and reduced graphene oxide ( $R G O$ )}

Firstly, graphite was treated with an $\mathrm{HCl}$ solution $(5 \mathrm{wt} \% / \mathrm{v})$. Then, it was filtered and washed with distilled water repeatedly to remove impurities. Finally, it was dried at $100{ }^{\circ} \mathrm{C}$ for $12 \mathrm{~h}$. The modified Hummers method ${ }^{4}$ was used for the $\mathrm{GO}$ synthesis. Briefly, graphite $(0.2 \mathrm{~g})$ previously treated was mixed with $\mathrm{NaNO}_{3}(0.25 \mathrm{~g})$ and $\mathrm{H}_{2} \mathrm{SO}_{4}(11.5 \mathrm{~mL})$ under magnetic stirring, at $0{ }^{\circ} \mathrm{C}$. Then, $\mathrm{KMnO}_{4}(1.5 \mathrm{~g})$ was added in small portions, keeping the temperature under $10{ }^{\circ} \mathrm{C}$. After that, the temperature was raised to $35^{\circ} \mathrm{C}$ and maintained for $2 \mathrm{~h}$. Distilled water $(80 \mathrm{~mL})$ was added in small portions, and the temperature increased to $90^{\circ} \mathrm{C}$ for $30 \mathrm{~min}$. The suspension was cooled to $20^{\circ} \mathrm{C}$, followed by the addition of $60 \mathrm{~mL}$ of $\mathrm{H}_{2} \mathrm{O}_{2}(10 \mathrm{wt} \% / \mathrm{v})$. The suspension was stirred $60 \mathrm{~min}$. GO was separated by centrifugation and washed three times with hydrogen peroxide $(10 \mathrm{wt} \% / \mathrm{v})$ and $\mathrm{H}_{2} \mathrm{SO}_{4}(5 \mathrm{wt} \% / \mathrm{v})$, followed by washing with distilled water until $\mathrm{pH}$ 6. After, it was filtered in a $0.45 \mu \mathrm{m}$ Nylon membrane and dried at $50{ }^{\circ} \mathrm{C}^{39}$. RGO was produced by thermal reduction of GO. The GO was dried at $150^{\circ} \mathrm{C}$ for $3 \mathrm{~h}$, and then it was calcined at $600{ }^{\circ} \mathrm{C}$ for $1 \mathrm{~min}$ with a heating rate of $30^{\circ} \mathrm{C} / \mathrm{min}$ in a muffle furnace in air atmosphere. The resulting RGO was sieved to obtain a uniform granulometry.

\section{$2.3 \mathrm{ZnO}$ and $\mathrm{ZnO}$-composites synthesis}

Pure $\mathrm{ZnO}, \mathrm{ZnO} / \mathrm{GO}$ composite with a mass ratio of 8 , and $\mathrm{ZnO} / \mathrm{RGO}$ composites with mass ratios of 100 and 600 were synthesized through the hydrothermal method, using urea as the precipitating agent. GO, or RGO was dispersed in $20 \mathrm{~mL}$ of deionized water with stirring followed by ultrasonication for $30 \mathrm{~min}$. The required amount of $\mathrm{Zn}\left(\mathrm{NO}_{3}\right)_{2} \cdot 6 \mathrm{H}_{2} \mathrm{O}$ and urea (four times the molar quantity of $\mathrm{Zn}^{2+}$ ) were solubilized in $80 \mathrm{~mL}$ of deionized water and mixed with GO or RGO suspension for $30 \mathrm{~min}$ under magnetic stirring. This suspension was transferred to a PTFE autoclave reactor and heated at $100{ }^{\circ} \mathrm{C}$ for $18 \mathrm{~h}$. After, the solid obtained was filtered and washed with deionized water until neutral $\mathrm{pH}$. It was dried at $50{ }^{\circ} \mathrm{C}$ for $12 \mathrm{~h}$ and calcined at $400{ }^{\circ} \mathrm{C}$ for $5 \mathrm{~h}$, with a heating rate of $10{ }^{\circ} \mathrm{C} / \mathrm{min}$. The samples were named as " $\mathrm{ZnO} / \mathrm{RGOx}$," where $\mathrm{x}$ means the mass ratio of $\mathrm{ZnO} / \mathrm{RGO}$ or $\mathrm{ZnO} / \mathrm{GO}$.

\subsection{Glass ionomer reinforcement}

Commercial GICs are composed of powder and liquid before use. The main components of the powder are silicon oxide, calcium chloride, sodium fluorosilicate, aluminum phosphate, and lyophilized polyacrylic acid. The liquid consists
Table 1 - Glass ionomer reinforced samples.

\begin{tabular}{ccc}
\hline Sample & Reinforcement & Proportion $\left(w t^{\%}\right)$ \\
\hline G1 & - & - \\
\hline G2 & ZnO & 3 \\
\hline G3 & RGO & 0.1 \\
\hline G4 & ZnO/GO8 & 3 \\
\hline G5 & ZnO/RGO100 & 3 \\
\hline G6 & ZnO/RGO600 & 3 \\
\hline
\end{tabular}

of tartaric acid and deionized water. The reinforcement was made with $\mathrm{RGO}$ in the proportion of $0.1 \mathrm{wt} \%$, and with $\mathrm{ZnO}$, $\mathrm{ZnO} / \mathrm{GO} 8, \mathrm{ZnO} / \mathrm{RGO} 100$ and $\mathrm{ZnO} / \mathrm{RGO} 600$ in the proportion of $3 \mathrm{wt} \%$ (Table 1 ). The different percentage of RGO added to the GIC was limited by experiments on the final color to keep it as close as possible to the pure GIC color, as shown in Figure 1. These composites were mixed with GIC powder using an amalgamator for 10 seconds. Then, it was mixed with the liquid following the manufacturer's instructions.

\subsection{Characterization}

Fourier transform infrared absorption spectroscopy (FTIR) was performed in transmission mode using a spectrometer Spectrum One (Perkin Elmer), in the range of 2000 to $400 \mathrm{~cm}^{-1}$, resolution of $4 \mathrm{~cm}^{-1}$ and 20 scans. The samples were diluted in $\mathrm{KBr}$ in the proportion of 2:300 (sample: $\mathrm{KBr}$ ), and the $\mathrm{KBr}$ pellet was used as a reference.

The field emission scanning electron microscopy (FEG-SEM) was performed in a Jeol microscope model JSM-7100F, using an acceleration voltage of $15 \mathrm{kV}$, and without metallic covering. X-ray diffraction (XRD) measurements were performed using a Rigaku Miniflex II diffractometer with $\mathrm{Cu}-\mathrm{K} \alpha$ radiation $(\lambda=1.5405 \AA)$. XRD data were collected in the range between $5^{\circ}<2 \theta<70^{\circ}$ and step size of $0.05^{\circ}$.

For the Laser Raman spectroscopy (LRS) analyses was used a LabRAM HR800 (Horiba-Jobin Yvon) micro-spectrometer, He-Ne laser (632 nm), CCD detector, and an OLYMPUS microscope, model BX41. The measurements were taken with $10 \mathrm{~s}$ beam exposure time, and 10 accumulations.

\subsection{Mechanical Tests}

The mechanical properties analyzed were compressive strength (CS), diametral tensile strength (DTS), and Knoop microhardness (KHN). Cylindrical specimens were prepared in Teflon molds, with dimensions of $4 \mathrm{~mm}$ diameter by $6 \mathrm{~mm}$ length, $6 \mathrm{~mm}$ diameter by $3 \mathrm{~mm}$ length and $6 \mathrm{~mm}$ diameter by $3 \mathrm{~mm}$ length, respectively.

The molds were slightly overfilled and covered with mylar strips. A glass plate was used to compress the surface for $10 \mathrm{~min}$, and then stored at $37^{\circ} \mathrm{C}$ in a humid environment. After $24 \mathrm{~h}$, the specimens were polished with a 1,200-grit silicon carbide paper (Buehler, Lake Bluff, IL, USA) until the excesses been removed. Twenty-five specimens of each material were prepared, and the Knoop hardness test was performed after $24 \mathrm{~h}$ on a hardness test machine (Shimadzu Micro Vickers Hardness Tester HMV-G), with 25 g load and $30 \mathrm{~s}$ dwell time. Five indentations were made on each specimen. 

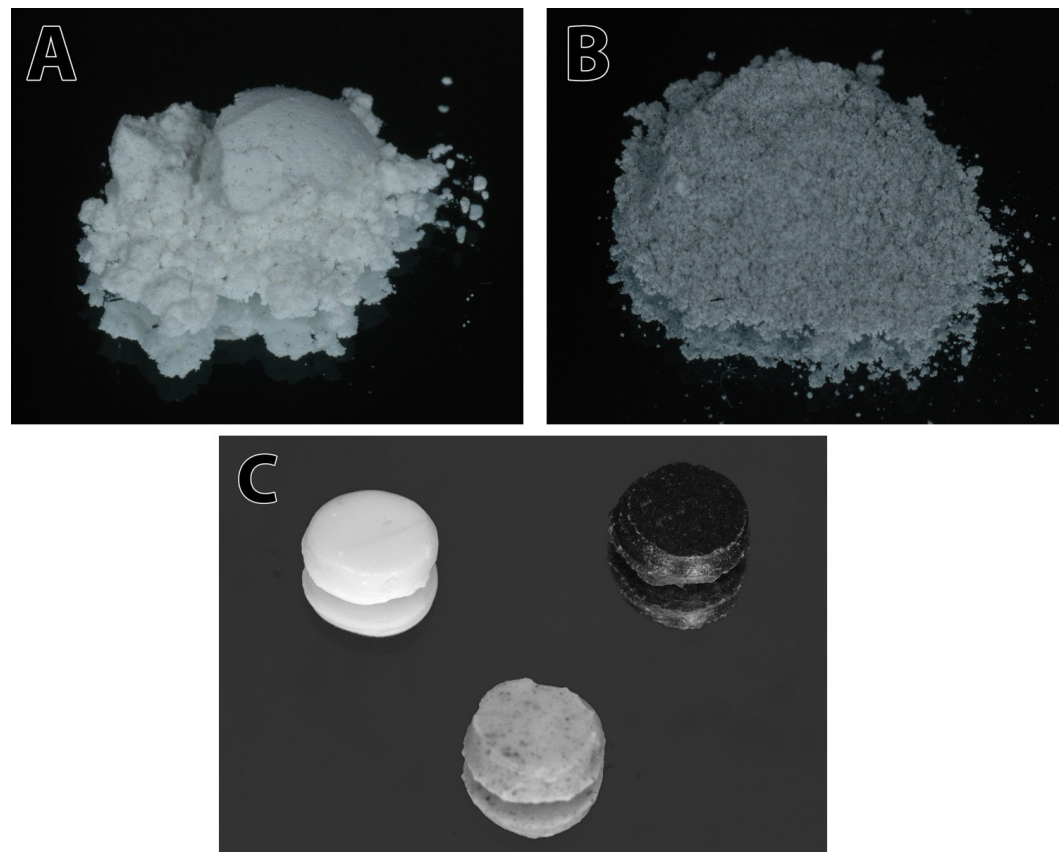

Figure 1. Glass ionomer powder with RGO in the proportion of $0.1 \%$ (A) and 3\% (B); samples of pure GIC and test GIC with RGO in the proportion of $0.1 \%$ and $3 \%$ after cure $(\mathrm{C})$.

Mechanical testing of specimens was performed on a screw-driven machine (DL 10.000, EMIC, São José dos Pinhais, PR, Brazil) with a crosshead speed of $0.5 \mathrm{~mm} / \mathrm{min}$ for the CS and DTS measurements. The sample sizes were $n=15$.

\subsection{Statistical analysis}

One-way analysis of variance (ANOVA) followed by Tukey's post hoc comparison test was used to test differences between groups at the level of significance of $p<0.05$ (SPSS 23, SPSS, IBM Corp.).

\section{Results and Discussion}

\section{$3.1 \mathrm{RGO}$ and $\mathrm{ZnO}$ composites characterization}

FTIR spectrum of the synthesized GO presented in Figure 2 shows bands related to oxygenated groups: $\mathrm{C}=\mathrm{O}$ at $1734 \mathrm{~cm}^{-1}$; $\mathrm{C}-\mathrm{OH}$ at $1400 \mathrm{~cm}^{-1}$; and $\mathrm{C}-\mathrm{O}$ at $1070 \mathrm{~cm}^{-1}$, confirming the oxidation of graphite ${ }^{39,40}$. For RGO, it was observed a decrease in the intensity of these bands, due to the reduction process. FTIR spectrum of $\mathrm{ZnO}$ and $\mathrm{ZnO}$ composites with GO and RGO are very similar. Noticeable are the bands at 571 and $415 \mathrm{~cm}^{-1}$ correlated to the zinc oxide ${ }^{40}$.

The $\mathrm{x}$-ray diffraction pattern of GO (Figure 3) presents a characteristic profile of a lamellar material. The peak at $2 \theta=10.85^{\circ}$ corresponds to an interlayer distance (d) of $0.814 \mathrm{~nm}$, which is related to the introduction of oxygenated groups, confirming the oxidation process ${ }^{39,40}$. In the RGO sample, the peak at $10.85^{\circ}$ disappears, which characterizes the reduction process, and a broad peak at $2 \theta=25.5^{\circ}$ appears, corresponding to an interlayer distance of $0.349 \mathrm{~nm}^{39,41}$. The diffraction pattern of synthesized $\mathrm{ZnO}$

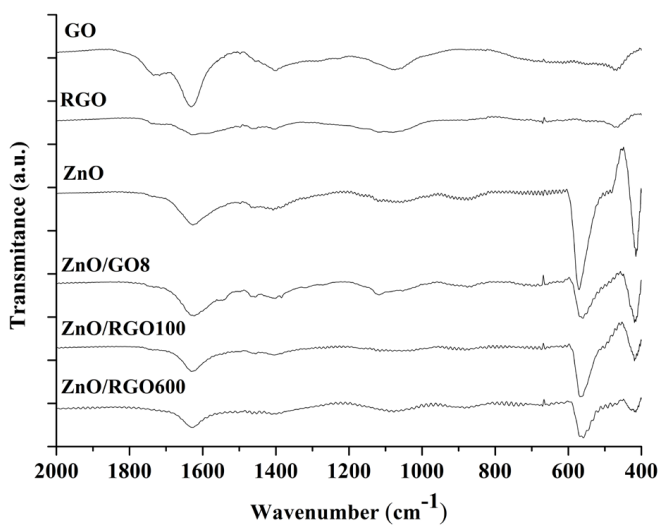

Figure 2. FTIR spectra of synthesized GO, RGO, ZnO, and composites.

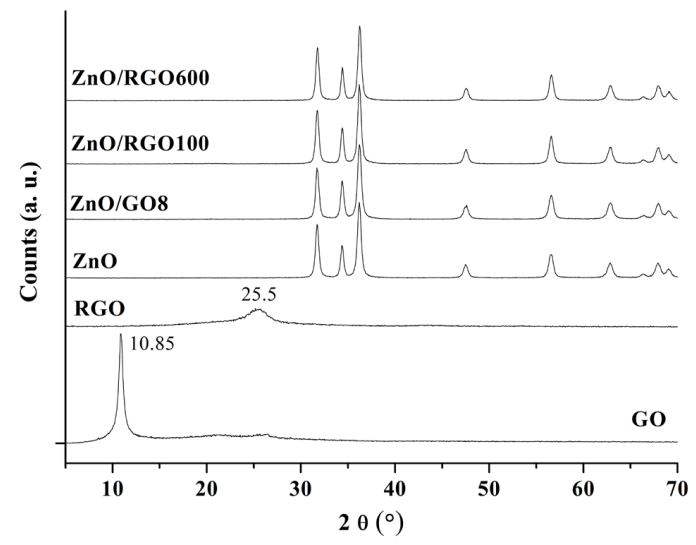

Figure 3. XR diffraction patterns of synthesized GO, RGO, ZnO, and composites. 
matches the standard of hexagonal wurtzite (PDF\#36-1451). The calculated crystallite size using Scherrer's equation is $18 \mathrm{~nm}\left(2 \theta=36.2^{\circ}\right)$. $\mathrm{ZnO} / \mathrm{GO} 8, \mathrm{ZnO} / \mathrm{RGO} 100$ and $\mathrm{ZnO} / \mathrm{RGO} 600$ diffractograms are very similar to pure $\mathrm{ZnO}$ diffractogram, and any peak related to GO or RGO were observed, which should be attributed to the small amount of these compounds in the composites.

The morphology of the samples obtained by FEG-SEM analyses is presented in Figure 4. The micrography of GO (Figure 4a) shows a sheet with wrinkles and folds, which is due to the interaction of oxygen groups present on the surface $^{39}$. RGO exhibits a change in the morphology, caused by the reduction process. It is observed a plane surface with sharp edges (Figure 4b). The GO reduction causes a restack of the sheets, as evidenced by an interlayer distance of $0.349 \mathrm{~nm}$, which is attributed to the decrease in the number of oxygen-containing groups present between the GO sheets. The value calculated for the number of restacked layers was eight and confirmed the formation of reduced graphene oxide ${ }^{42}$.

Concerning to $\mathrm{ZnO}$ and the composites, in general, the morphology of the zinc oxide was predominant for all the samples (Figure 5), and it should be due to the high content of the oxide. The $\mathrm{ZnO}$ morphology depends on the conditions used in the preparation method, and it could form nanorods, nanoflowers, nanoneedles, nanodisks ${ }^{43-45}$. During the hydrothermal synthesis used in the present study, there was the hydrolysis of urea with a slow-releasing of $\mathrm{OH}^{-}$and $\mathrm{CO}_{3}{ }^{2-}$ ions (Equations 1-3). These species react with $\mathrm{Zn}^{2+}$, leading to the precipitation of a zinc hydroxide carbonate (Equation 4). With heat treatment at $400{ }^{\circ} \mathrm{C}$, this precursor is converted into $\mathrm{ZnO}$ and forming $\mathrm{H}_{2} \mathrm{O}$ and $\mathrm{CO}_{2}$ (Equation 5) ${ }^{45-49}$

$$
\begin{aligned}
& \mathrm{CO}\left(\mathrm{NH}_{2}\right)_{2}+\mathrm{H}_{2} \mathrm{O} \rightarrow 2 \mathrm{NH}_{3}+\mathrm{CO}_{2} \\
& \mathrm{CO}_{2}+\mathrm{H}_{2} \mathrm{O} \rightarrow \mathrm{CO}_{3}^{2-}+2 \mathrm{H}^{+} \\
& \mathrm{NH}_{3} \cdot \mathrm{H}_{2} \mathrm{O} \rightarrow \mathrm{NH}_{4}^{+}+\mathrm{OH}^{-} \\
& 5 \mathrm{Zn}^{2+}+2 \mathrm{CO}_{3}^{2-}+6 \mathrm{OH}^{-} \rightarrow \mathrm{Zn}_{5}(\mathrm{OH})_{6}\left(\mathrm{CO}_{3}\right)_{2}
\end{aligned}
$$

$$
\mathrm{Zn}_{5}(\mathrm{OH})_{6}\left(\mathrm{CO}_{3}\right)_{2} \stackrel{\Delta}{\rightarrow} 5 \mathrm{ZnO}+3 \mathrm{H}_{2} \mathrm{O}+2 \mathrm{CO}_{2}
$$

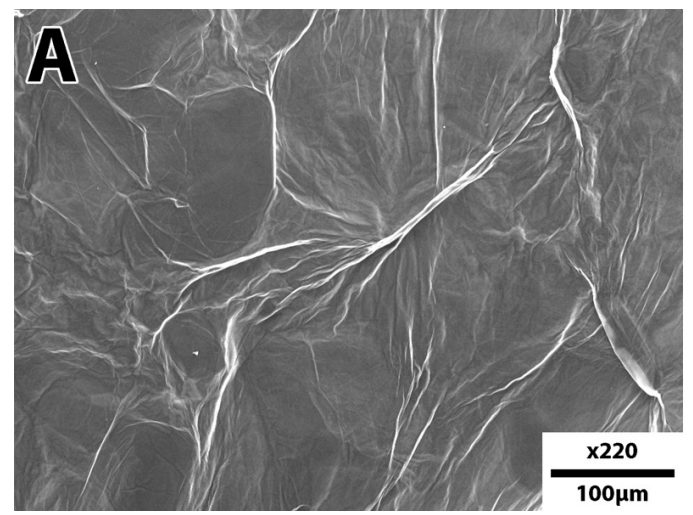

In this work, we obtained an oxide with flower-like morphology and nanostructured petals (Figure 5a-b). For $\mathrm{ZnO} / \mathrm{GO} 8$ sample, the sheets of GO were not evident in the micrography probably because they are skinny (Figure 5c-d). The ZnO/RGO100 presents bigger particles than $\mathrm{ZnO} / \mathrm{GO} 8$, with the same flower-like morphology (Figure 5e); however, in this sample, it was possible to observe RGO sheets together with $\mathrm{ZnO}$ particle (Figure 5f). The $\mathrm{ZnO} / \mathrm{RGO} 600$ sample showed the same characteristics of $\mathrm{ZnO} / \mathrm{RGO} 100$ (Figure 5g-h). These results are in accordance with XRD, where the $\mathrm{ZnO}$ phase was predominant and well ordered.

Therefore, the results confirmed the formation of the composites where the zinc hydroxide carbonate formed during the hydrothermal synthesis anchored in GO or RGO sheets through the oxygenated groups on the surface $40,50,51$ and growing up forming the flower-like morphology.

The Raman spectra of GO and RGO (Figure 6a) show D $\left(1336 \mathrm{~cm}^{-1}\right)$ and $\mathrm{G}\left(1590 \mathrm{~cm}^{-1}\right)$ bands, corresponding to carbon-carbon vibrations that are actives in the presence of defects and $\mathrm{Csp}^{2}$ bonds, respectively ${ }^{52-54}$. The ratio $\mathrm{I}_{\mathrm{D}} / \mathrm{I}_{\mathrm{G}}$ that is an indication of defects had a value of 1.01 for $\mathrm{GO}$ and 1.16 for $\mathrm{RGO}$, which suggests a decrease in the $\mathrm{sp}^{2}$ domains, and confirms the reduction of $\mathrm{GO}^{50}$. Concerning to $\mathrm{ZnO}$ and the composites (Figure 6b), it was observed that $\mathrm{ZnO}$ spectrum shows peaks at $438 \mathrm{~cm}^{-1}$, corresponding to E2 (high) mode of the wurtzite structure; at $332 \mathrm{~cm}^{-1}$, due to $3 \mathrm{E} 2 \mathrm{H}-\mathrm{E} 2 \mathrm{~L}$ phonon mode; at $381 \mathrm{~cm}^{-1}$, corresponding to A1T mode related to the structural order-disorder in the lattice; and at $1108 \mathrm{~cm}^{-1}$, which corresponds to 2A1 (LO) and 2E1 (LO) modes of the Brillouin zone of $\mathrm{ZnO}^{45,52,55}$. The composites $\mathrm{ZnO} / \mathrm{GO} 8$ and $\mathrm{ZnO} / \mathrm{RGO} 600$ presented the bands of $\mathrm{D}$ and $\mathrm{G}$ vibrational modes related to $\mathrm{GO}$ and $\mathrm{RGO}$ along with the bands of the zinc oxide phase. Also, the Raman results were complementary to the $\mathrm{XRD}$, once showed the presence of the carbon and zinc phases in the composites, which was not observed in the XRD results (Figure 3).

\subsection{Mechanical tests}

GIC is a brittle restorative material and often fails by the voids and cracks in the matrix. The reinforcement by fillers seems to be a viable option to improve its mechanical performance and extend its longevity and indications. Other previous studies showed that graphene and its derivatives

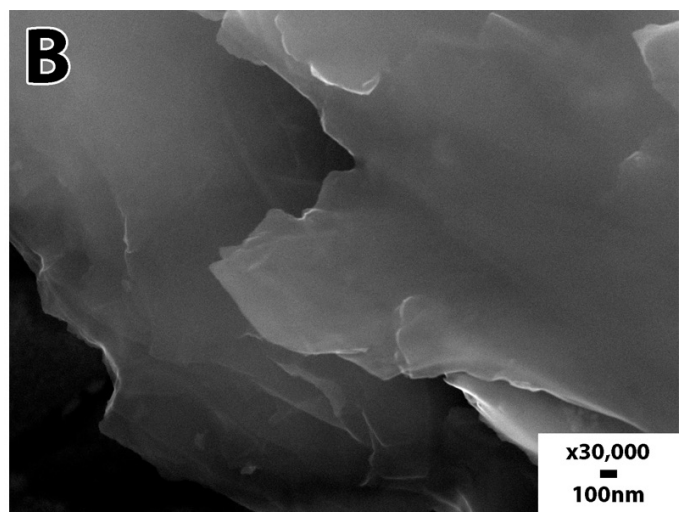

Figure 4. FEG-SEM images of GO (A); and RGO (B). 

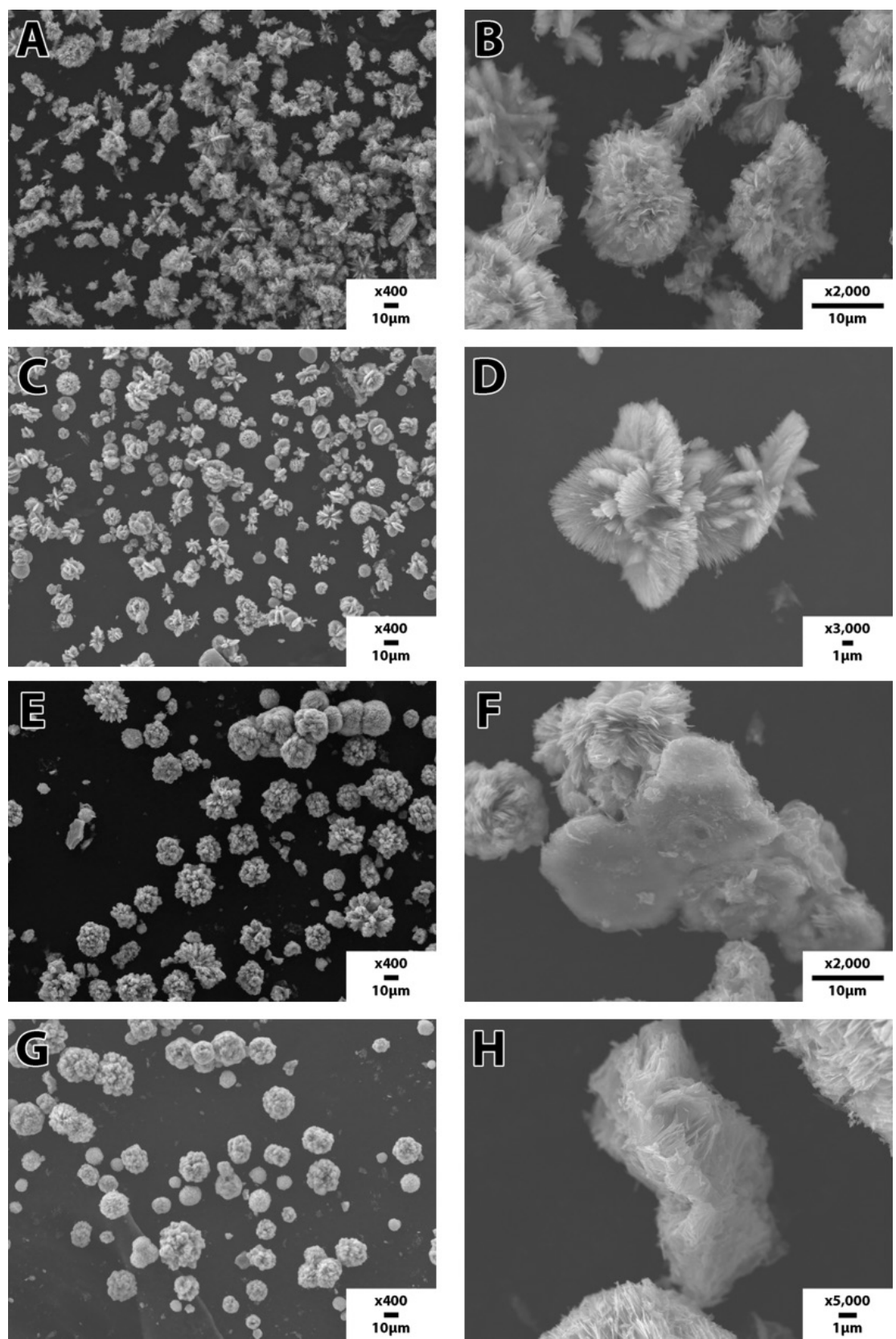

Figure 5. FEG-SEM images of: ZnO (A, B); ZnO/GO8 (C, D); ZnO/RGO100 (E, F); and ZnO/RGO600 (G, H).
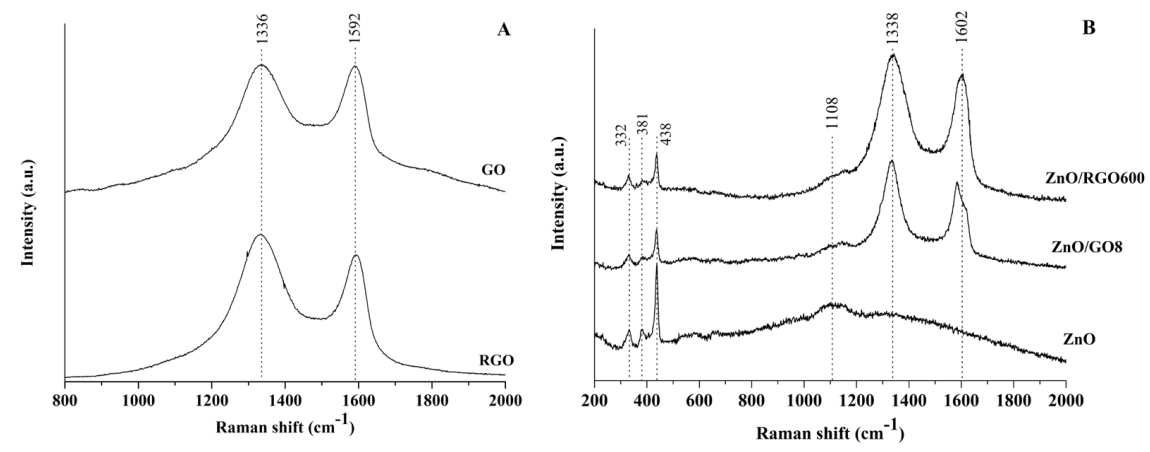

Figure 6. Raman spectra of $\mathrm{GO}$ and $\mathrm{RGO}(\mathrm{A})$, and $\mathrm{ZnO}, \mathrm{ZnO} / \mathrm{GO}$ and $\mathrm{ZnO} / \mathrm{RGO} 600$ (B). 
could enhance the physical and mechanical properties of cementitious products $33,38,56$. There is some hypothesis to explain the enhancement of mechanical properties, but the more suitable refers to the crack branching mechanism which is composed of four distinct aspects: crack bridging, pull-out, crack deflection and crack tip shielding ${ }^{57}$. The crack-bridging occurs when $\mathrm{ZnO} / \mathrm{GO}$ bridges the opposite surface or crack and alleviates the force of crack propagation. The pull-out mechanism happens when the shear force is larger than the interface strength, so the friction between graphene and matrix hamper their relative motion. The cement matrix requires more energy to cause the nano-filler to pull out. The crack deflection is related to the $2 \mathrm{D}$ nanosheet structure of graphene that can transfer the stress on graphene to another graphene sheet, and it generates a tortuous path for crack propagation, which dissipate much more energy. The tip shielding mechanism says that, when a crack propagates to graphene, it is restricted to the vicinity of the graphene sheet because the energy is insufficient to create a gap in the interface.

Table 2 present the results of each group. Tables 3, 4, and 5 show the groups without significant difference through homogeneous subsets for compressive strength (CS), diametral tensile strength (DTS), and Knoop microhardness (KHN), respectively.

The synthesized materials show different behavior in mechanical testing when compared to pure GIC (G1).

Table 2 - Results of KHN, CS, and DTS of each group.

\begin{tabular}{lccccccc}
\hline & \multirow{2}{*}{$\mathrm{G} 1$} & \multirow{2}{*}{$\mathrm{G} 2$} & \multirow{2}{*}{$\mathrm{G} 3$} & \multirow{2}{*}{ G4 } & \multirow{2}{*}{ G5 } & G6 & \multicolumn{2}{c}{ ANOVA } \\
\hline KHN & $38.47(2.44)^{*}$ & $41.15(1.14)$ & $39.99(1.29)$ & $40.8(0.65)$ & $40.56(0.92)$ & $40.48(0.83)$ & 0.00 \\
\hline CS $(\mathrm{MPa})$ & $59.57(10.76)$ & $56.31(8.2)$ & $53.33(6.58)$ & $39.82(6.1)$ & $48.52(13.09)$ & $55.67(4.14)$ & 0.00 \\
\hline DTS $(\mathrm{MPa})$ & $10.92(1.58)$ & $9.32(2.33)$ & $11.59(2.37)$ & $9.01(1.51)$ & $7.51(2.36)$ & $10.61(4.05)$ & 0.00 \\
\hline * Average and standard deviation & & & & & &
\end{tabular}

Table 3 - Means of compressive strength (CS) for groups in homogeneous subsets.

\begin{tabular}{|c|c|c|c|c|c|}
\hline \multicolumn{6}{|c|}{$\mathrm{CS}(\mathrm{MPa})$} \\
\hline & \multirow{2}{*}{ GROUP } & \multirow{2}{*}{$\mathrm{N}$} & \multicolumn{3}{|c|}{ Subset for alpha $=0.05$} \\
\hline & & & 1 & 2 & 3 \\
\hline \multirow{7}{*}{ Tukey HSD } & 4 & 15 & 39.82 & & \\
\hline & 5 & 15 & 48.53 & 48.53 & \\
\hline & 3 & 15 & & 53.34 & 53.34 \\
\hline & 6 & 15 & & 55.67 & 55.67 \\
\hline & 2 & 15 & & 56.31 & 56.31 \\
\hline & 1 & 15 & & & 59.57 \\
\hline & Sig. & & 0.077 & 0.150 & 0.371 \\
\hline
\end{tabular}

Table 4 - Means of the diametral tensile strength (DTS) of groups in homogeneous subsets.

\begin{tabular}{|c|c|c|c|c|}
\hline \multicolumn{5}{|c|}{ DTS (MPa) } \\
\hline & \multirow{2}{*}{ GROUP } & \multirow{2}{*}{$\mathrm{N}$} & \multicolumn{2}{|c|}{ Subset for alpha $=0.05$} \\
\hline & & & 1 & 2 \\
\hline \multirow{7}{*}{ Tukey HSD ${ }^{\mathrm{a}}$} & 5 & 15 & 7.52 & \\
\hline & 4 & 15 & 9.01 & 9.01 \\
\hline & 2 & 15 & 9.32 & 9.32 \\
\hline & 6 & 15 & & 10.62 \\
\hline & 1 & 15 & & 10.92 \\
\hline & 3 & 15 & & 11.59 \\
\hline & Sig. & & 0.372 & 0.066 \\
\hline
\end{tabular}

Table 5 - Means of Knoop microhardness (KHN) of groups in homogeneous subsets.

\begin{tabular}{|c|c|c|c|c|c|}
\hline \multicolumn{6}{|c|}{$\mathrm{KHN}$} \\
\hline & \multirow{2}{*}{ GROUP } & \multirow{2}{*}{$\mathrm{N}$} & \multicolumn{3}{|c|}{ Subset for alpha $=0.05$} \\
\hline & & & 1 & 2 & 3 \\
\hline \multirow{7}{*}{ Tukey HSD ${ }^{\mathrm{a}}$} & 1 & 25 & 38.47 & & \\
\hline & 3 & 25 & & 40.00 & \\
\hline & 6 & 25 & & 40.48 & 40.48 \\
\hline & 5 & 25 & & 40.57 & 40.57 \\
\hline & 4 & 25 & & 40.80 & 40.80 \\
\hline & 2 & 25 & & & 41.16 \\
\hline & Sig. & & 1.000 & 0.296 & 0.488 \\
\hline
\end{tabular}


Although G3 presented the highest DTS values, there was no statistical difference from G1. For CS, the best results were observed for G1. The differences between the groups were either not statistically significant or, when they were, insufficiently consistent to conclude the optimal composition. Probably the results obtained will serve as a basis for new formulations. Only KHN showed significant improvement for all 5 groups when compared to G1.

Nevertheless, this difference is not clinically impactful, as it would not significantly improve the material properties, which could broaden its indications for use. Only KHN showed significant improvement for all 5 groups when compared to G1. The small amount of RGO or GO used in the reinforced GICs might explain these modest changes.

\section{Conclusions}

The syntheses of the studied materials resulted in the formation of a GO with an interlayer distance $(d)$ of $0.814 \mathrm{~nm}$, characteristic of lamellar structures, and sheets with wrinkles and folds morphology. After reduction, the sheets restacked and formed RGO. Nanostructured Zinc oxide as a wurtzite phase was formed with crystallite size with $18 \mathrm{~nm}$ and morphology similar to flowers. The $\mathrm{ZnO} / \mathrm{RGO}$ composites presented the same structural and morphological characteristics as pure $\mathrm{ZnO}$, independent of the $\mathrm{ZnO} / \mathrm{RGO}$ ratio. The GO and RGO sheets acted as a seed to anchor the zinc hydroxide carbonate formed during the hydrothermal synthesis and growing up forming the flower-like morphology.

The incorporation of different graphene composites contents induced to slight improvements in hardness. Although promising, the incorporation of graphene to reinforce the structure of the GIC should be better studied to obtain the synthesis of material with better general properties, and that extend its possibilities of use.

\section{Acknowledgments}

The authors would like to thank Nanofab/UERJ for SEM analyses, the Laboratory of Instrumental Characterization/UERJ for the infrared spectroscopy analyses, and the LACAT/DICAP/INT for the Laser Raman Spectroscopy analyses.

This study was financed in part by the Coordenação de Aperfeiçoamento de Pessoal de Nível Superior - Brazil (CAPES) - Finance Code 001.

This work was also supported by Universidade do Estado do Rio de Janeiro (Brazil) and Fundação Carlos Chagas Filho de Amparo à Pesquisa do Estado do Rio de Janeiro (FAPERJ, Brazil).

\section{References}

1. Bai H, Li C, Shi G. Functional composite materials based on chemically converted graphene. Adv Mater. 2011;23(9):1089-115. http://dx.doi.org/10.1002/adma.201003753. PMid:21360763.

2. Baig MS, Fleming GJP. Conventional glass-ionomer materials: a review of the developments in glass powder, polyacid liquid and the strategies of reinforcement. J Dent. 2015;43(8):897-912. http://dx.doi.org/10.1016/j.jdent.2015.04.004. PMid:25882584.

3. Guerrero-Contreras J, Caballero-Briones F. Graphene oxide powders with different oxidation degree, prepared by synthesis variations of the Hummers method. Mater Chem Phys. 2015;153:209-20. http://dx.doi.org/10.1016/j.matchemphys.2015.01.005.
4. Hummers WS Jr, Offeman RE. Preparation of graphitic oxide. J Am Chem Soc. 1958;80(6):1339-1339. http://dx.doi.org/10.1021/ ja01539a017.

5. Xu C, Wang X, Zhu J. Graphene--metal particle nanocomposites. J Phys Chem C. 2008;112(50):19841-5. http://dx.doi.org/10.1021/ jp807989b.

6. Yan L, Yu J, Luo H. Ultrafine $\mathrm{TiO} 2$ nanoparticles on reduced graphene oxide as anode materials for lithium ion batteries. Appl Mater Today. 2017;8:31-4. http://dx.doi.org/10.1016/j. apmt.2017.02.001.

7. Zhu C, Guo S, Fang Y, Dong S. Reducing sugar: new functional molecules for the green synthesis of graphene nanosheets. ACS Nano. 2010;4(4):2429-37. http://dx.doi.org/10.1021/nn1002387. PMid:20359169.

8. Zhang J, Yang H, Shen G, Cheng P, Zhang J, Guo S. Reduction of graphene oxide via l-ascorbic acid. Chem Commun (Camb). 2010;46(7):1112-4. http://dx.doi.org/10.1039/B917705A. PMid:20126730.

9. Gao W, Alemany LB, Ci L, Ajayan PM. New insights into the structure and reduction of graphite oxide. Nat Chem. 2009;1(5):4038. http://dx.doi.org/10.1038/nchem.281. PMid:21378895.

10. Fernández-Merino MJ, Guardia L, Paredes JI, Villar-Rodil $\mathrm{S}$, Solís-Fernández P, Martínez-Alonso A, et al. Vitamin C is an ideal substitute for hydrazine in the reduction of graphene oxide suspensions. J Phys Chem C. 2010;114(14):6426-32. http://dx.doi.org/10.1021/jp100603h.

11. McNaught AD, Wilkinson A, organizadores. IUPAC: Compendium of chemical terminology (2nd ed). Oxford: Blackwell Scientific Publications; 1997.

12. Han X, Huang Y, Gao Q, Fan R, Peng X. Effects of nanotube content on thermal and mechanical properties of NT@Cu/Ag@ GF/Al composites. J Alloys Compd. 2018;766:594-600. http:// dx.doi.org/10.1016/j.jallcom.2018.06.333.

13. Han X, Huang Y, Gao Q, Yu M, Chen X. High thermal conductivity and mechanical properties of nanotube@Cu/Ag@Graphite/ aluminum composites. Ind Eng Chem Res. 2018;57(31):1036571. http://dx.doi.org/10.1021/acs.iecr.8b01567.

14. Han X, Huang Y, Zhou S, Sun X, Peng X, Chen X. Effects of graphene content on thermal and mechanical properties of chromium-coated graphite flakes/Si/Al composites. J Mater Sci Mater Electron. 2018;29(5):4179-89. http://dx.doi.org/10.1007/ s10854-017-8363-7.

15. Luo Z, Li H, Yang Y, Lin H, Yang Z. Adsorption of $17 \alpha$-ethinylestradiol from aqueous solution onto a reduced graphene oxide-magnetic composite. J Taiwan Inst Chem Eng. 2017;80:797-804. http://dx.doi.org/10.1016/j.jtice.2017.09.028.

16. Du Q, Zheng M, Zhang L, Wang Y, Chen J, Xue L, et al. Preparation of functionalized graphene sheets by a low-temperature thermal exfoliation approach and their electrochemical supercapacitive behaviors. Electrochim Acta. 2010;55(12):3897-903. http:// dx.doi.org/10.1016/j.electacta.2010.01.089.

17. Yang X, Zhang X, Ma Y, Huang Y, Wang Y, Chen Y. Superparamagnetic graphene oxide-Fe3O4 nanoparticles hybrid for controlled targeted drug carriers. J Mater Chem. 2009;19(18):2710. http://dx.doi.org/10.1039/b821416f.

18. Boruah PK, Borah DJ, Handique J, Sharma P, Sengupta P, Das MR. Facile synthesis and characterization of $\mathrm{Fe} 3 \mathrm{O} 4$ nanopowder and $\mathrm{Fe} 3 \mathrm{O} 4 /$ reduced graphene oxide nanocomposite for methyl blue adsorption: a comparative study. J Environ Chem Eng. 2015;3(3):1974-85. http://dx.doi.org/10.1016/j.jece.2015.06.030.

19. Lee C, Wei X, Kysar JW, Hone J. Measurement of the elastic properties and intrinsic strength of monolayer graphene. Science. 2008;321(5887):385-8. http://dx.doi.org/10.1126/ science.1157996. PMid:18635798.

20. Zhao Y, Sun KN, Wang WL, Wang YX, Sun XL, Liang YJ, et al. Microstructure and anisotropic mechanical properties of graphene nanoplatelet toughened biphasic calcium phosphate composite. 
Ceram Int. 2013;39(7):7627-34. http://dx.doi.org/10.1016/j. ceramint.2013.03.018.

21. Sidhu S, Nicholson J. A review of glass-ionomer cements for clinical dentistry. J Funct Biomater. 2016;7(3):16. http://dx.doi. org/10.3390/jfb7030016. PMid:27367737.

22. Stober T, Rammelsberg $P$. The failure rate of adhesively retained composite core build-ups in comparison with metal-added glass ionomer core build-ups. J Dent. 2005;33(1):27-32. http://dx.doi. org/10.1016/j.jdent.2004.07.006. PMid:15652165.

23. Berzins DW, Abey S, Costache MC, Wilkie CA, Roberts HW. Resin-modified glass-ionomer setting reaction competition. J Dent Res. 2010;89(1):82-6. http://dx.doi.org/10.1177/0022034509355919. PMid: 19966038.

24. Sidhu SK. Clinical evaluations of resin-modified glass-ionomer restorations. Dent Mater. 2010;26(1):7-12. http://dx.doi. org/10.1016/j.dental.2009.08.015. PMid:19801167.

25. Garoushi SK, He J, Vallittu PK, Lassila LVJ. Effect of discontinuous glass fibers on mechanical properties of glass ionomer cement. Acta Biomater Odontol Scand. 2018;4(1):72-80. http://dx.doi. org/10.1080/23337931.2018.1491798. PMid:30083578.

26. Mobarak EH, Shabayek MM, El-Deeb HA, Mulder J, Hassan FM, Van der Sanden WJM, et al. Survival of occlusal ART restorations using high-viscosity glass-ionomer with and without chlorhexidine: A 2-year split-mouth quadruple-blind randomized controlled clinical trial. J Adv Res. 2019;17:117-23. http://dx.doi.org/10.1016/j.jare.2019.01.015. PMid:31193330.

27. da Silva MER, Danelon M, Santos Souza JA, Silva DF, Pereira JA, Pedrini D, et al. Incorporation of chlorhexidine and nano-sized sodium trimetaphosphate into a glass-ionomer cement: effect on mechanical and microbiological properties and inhibition of enamel demineralization. J Dent. 2019;84(March):81-8. http:// dx.doi.org/10.1016/j.jdent.2019.04.001. PMid:30953673.

28. Zanni E, Chandraiahgari C, De Bellis G, Montereali M, Armiento G, Ballirano P, et al. Zinc oxide nanorods-decorated graphene nanoplatelets: a promising antimicrobial agent against the cariogenic bacterium streptococcus mutans. Nanomaterials (Basel). 2016;6(10):179. http://dx.doi.org/10.3390/nano6100179. PMid:28335307.

29. Garcia PPNS, Cardia MFB, Francisconi RS, Dovigo LN, Spolidório DMP, de Souza Rastelli AN, et al. Antibacterial activity of glass ionomer cement modified by zinc oxide nanoparticles. Microsc Res Tech. 2017;80(5):456-61. http:// dx.doi.org/10.1002/jemt.22814. PMid:27935662.

30. Agarwal P, Nayak R, Upadhya PN, Ginjupalli K, Gupta L. Evaluation of properties of glass ionomer cement reinforced with zinc oxide nanoparticles - an in vitro study. Mater Today Proc. 2018;5(8):16065-72. http://dx.doi.org/10.1016/j. matpr.2018.05.088.

31. Xie H, Cao T, Rodríguez-Lozano FJ, Luong-Van EK, Rosa V. Graphene for the development of the next-generation of biocomposites for dental and medical applications. Dent Mater. 2017;33(7):765-74. http://dx.doi.org/10.1016/j.dental.2017.04.008. PMid:28495017.

32. Shi L, Bai Y, Su J, Ma W, Jia R. Graphene oxide/fluorhydroxyapatite composites with enhanced chemical stability, mechanical, and biological properties for dental applications. Int J Appl Ceram Technol. 2017;14(6):1088-100. http://dx.doi.org/10.1111/ ijac. 12712 .

33. Dubey N, Rajan SS, Bello YD, Min K-S, Rosa V. Graphene nanosheets to improve physico-mechanical properties of bioactive calcium silicate cements. Materials (Basel). 2017;10(6):606. http://dx.doi.org/10.3390/ma10060606. PMid:28772959.

34. Alamgir M, Nayak GC, Mallick A, Tiwari SK, Mondal S, Gupta M. Processing of PMMA nanocomposites containing biocompatible GO and TiO 2 nanoparticles. Mater Manuf Process. 2018;33(12):1291-8. http://dx.doi.org/10.1080/1042 6914.2018.1424996.
35. Bacali C, Badea M, Moldovan M, Sarosi C, Nastase V, Baldea I, et al. The Influence of Graphene in Improvement of Physico-Mechanical Properties in PMMA Denture Base Resins. Materials (Basel). 2019;12(14):2335. http://dx.doi.org/10.3390/ ma12142335. PMid:31340462.

36. Lee JH, Jo JK, Kim DA, Patel KD, Kim HW, Lee HH. Nanographene oxide incorporated into PMMA resin to prevent microbial adhesion. Dent Mater. 2018;34(4):e63-72. http:// dx.doi.org/10.1016/j.dental.2018.01.019. PMid:29402540.

37. Malik S, Ruddock FM, Dowling AH, Byrne K, Schmitt W, Khalakhan I, et al. Graphene composites with dental and biomedical applicability. Beilstein J Nanotechnol. 2018;9(1):8018. http://dx.doi.org/10.3762/bjnano.9.73. PMid:29600141.

38. Sun L, Yan Z, Duan Y, Zhang J, Liu B. Improvement of the mechanical, tribological and antibacterial properties of glass ionomer cements by fluorinated graphene. Dent Mater. 2018;34(6):e115-27. http://dx.doi.org/10.1016/j.dental.2018.02.006. PMid:29567317.

39. Soares CPP, Baptista R L, Cesar DV. Solvothermal reduction of graphite oxide using alcohols. Mater Res. 2018;21(1):1-7.

40. Saravanakumar B, Mohan R, Kim S-J. Facile synthesis of graphene/ZnO nanocomposites by low temperature hydrothermal method. Mater Res Bull. 2013;48(2):878-83. http://dx.doi. org/10.1016/j.materresbull.2012.11.048.

41. Nipane SV, Korake PV, Gokavi GS. Graphene-zinc oxide nanorod nanocomposite as photocatalyst for enhanced degradation of dyes under UV light irradiation. Ceram Int. 2015;41(3):454957. http://dx.doi.org/10.1016/j.ceramint.2014.11.151.

42. Botas C, Álvarez P, Blanco C, Santamaría R, Granda M, Gutiérrez MD, et al. Critical temperatures in the synthesis of graphene-like materials by thermal exfoliation-reduction of graphite oxide. Carbon N Y. 2013;52:476-85. http://dx.doi. org/10.1016/j.carbon.2012.09.059.

43. Kharisov B. A review for synthesis of nanoflowers. Recent Pat Nanotechnol. 2008;2(3):190-200. http://dx.doi. org/10.2174/187221008786369651. PMid:19076053.

44. Baruah S, Dutta J. Hydrothermal growth of $\mathrm{ZnO}$ nanostructures. Sci Technol Adv Mater. 2009;10(1):013001. http://dx.doi. org/10.1088/1468-6996/10/1/013001. PMid:27877250.

45. Marinho JZ, Romeiro FC, Lemos SCS, Motta FV, Riccardi CS, Li MS, et al. Urea-based synthesis of zinc oxide nanostructures at low temperature. J Nanomater. 2012;2012:1-7. http://dx.doi. org/10.1155/2012/427172.

46. Zhou Q, Xing J, Gao Y, Lv X, He Y, Guo Z, et al. Ordered assembly of NiCo2O4 multiple hierarchical structures for highperformance pseudocapacitors. ACS Appl Mater Interfaces. 2014;6(14):11394-402. http://dx.doi.org/10.1021/am501988s. PMid:24992821.

47. Xiao J, Yang S. Sequential crystallization of sea urchin-like bimetallic (Ni, Co) carbonate hydroxide and its morphology conserved conversion to porous $\mathrm{NiCo} 2 \mathrm{O} 4$ spinel for pseudocapacitors. RSC Advances. 2011;1(4):588-95. http://dx.doi.org/10.1039/ c1ra00342a.

48. Musić S, Popović S, Maljković M, Dragčević D. Influence of synthesis procedure on the formation and properties of zinc oxide. J Alloys Compd. 2002;347(1-2):324-32. http://dx.doi. org/10.1016/S0925-8388(02)00792-2.

49. Bitenc M, Marinšek M, Crnjak Orel Z. Preparation and characterization of zinc hydroxide carbonate and porous zinc oxide particles. J Eur Ceram Soc. 2008;28(15):2915-21. http:// dx.doi.org/10.1016/j.jeurceramsoc.2008.05.003.

50. Zhou X, Shi T, Zhou H. Hydrothermal preparation of ZnO-reduced graphene oxide hybrid with high performance in photocatalytic degradation. Appl Surf Sci. 2012;258(17):6204-11. http://dx.doi. org/10.1016/j.apsusc.2012.02.131

51. Chandraiahgari CR, De Bellis G, Balijepalli SK, Kaciulis S, Ballirano P, Migliori A, et al. Control of the size and density of $\mathrm{ZnO}$-nanorods grown onto graphene nanoplatelets in aqueous 
suspensions. RSC Advances. 2016;6(86):83217-25. http:// dx.doi.org/10.1039/C6RA18317D.

52. Romeiro FC, Rodrigues MA, Silva LAJ, Catto AC, da Silva LF, Longo E, et al. rGO-ZnO nanocomposites for high electrocatalytic effect on water oxidation obtained by microwavehydrothermal method. Appl Surf Sci. 2017;423:743-51. http:// dx.doi.org/10.1016/j.apsusc.2017.06.221.

53. Ghosh S, Ganesan K, Polaki SR, Ravindran TR, Krishna NG, Kamruddin M, et al. Evolution and defect analysis of vertical graphene nanosheets. J Raman Spectrosc. 2014;45(8):642-9. http://dx.doi.org/10.1002/jrs.4530.

54. Kudin KN, Ozbas B, Schniepp HC, Prud'homme RK, Aksay IA, Car R. Raman spectra of graphite oxide and functionalized graphene sheets. Nano Lett. 2008;8(1):36-41. http://dx.doi. org/10.1021/n1071822y. PMid:18154315.

55. Özgür Ü, Alivov YI, Liu C, TekeA, Reshchikov MA, Doğan S, et al. A comprehensive review of $\mathrm{ZnO}$ materials and devices. J Appl Phys. 2005;98(4):041301. http://dx.doi.org/10.1063/1.1992666.

56. Zhang L, Liu W, Yue C, Zhang T, Li P, Xing Z, et al. A tough graphene nanosheet/hydroxyapatite composite with improved in vitro biocompatibility. Carbon N Y. 2013;61:105-15. http:// dx.doi.org/10.1016/j.carbon.2013.04.074.

57. Baradaran S, Moghaddam E, Basirun WJ, Mehrali M, Sookhakian M, Hamdi M, et al. Mechanical properties and biomedical applications of a nanotube hydroxyapatite-reduced graphene oxide composite. Carbon N Y. 2014;69:32-45. http://dx.doi. org/10.1016/j.carbon.2013.11.054. 